\title{
A New Model Consisting Pulmonary Rehabilitation Program For Weaning
}

\section{Weaning İçin Pulmoner Rehabilitasyon Programı İçeren Yeni Bir Model}

\author{
Ipek CANDEMIR๑, Dicle KAYMAZ $\oplus$, Fatma AKTAS $\oplus$, Pinar ERGUN®
}

Cite as: Candemir I, Kaymaz D, Aktas F, Ergun P. A new model consisting pulmonary rehabilitation program for weaning. İzmir Gögüs Hastanesi Dergisi. 2020;34(2):62-70.

\begin{abstract}
Objective: Our chronic respiratory failure service where we manage the patients with acute /chronic respiratory failure, is a hospital unit with multidisciplinary team with structured integrated pulmonary rehabilitation (PR) and home care unit. The aim of the study was to present our weaning experiences of inpatient hospital service in patients with prolonged mechanical ventilation $(\mathrm{MV})$ and whether multidisciplinary structured inpatient service model could be an alternative method for weaning.

Method: Twenty-three patients with home invasive mechanical ventilation (IMV) who underwent multidisciplinary inpatient PR program and weaning trials were analyzed. Dyspnea scores, body composition, respiratory muscle strength, physicological status, echocardiagraphic measurements before PR and weaning process, duration of IMV (since the opening of the tracheostomy), ABG levels before and 24 hours after weaning were recorded.

Results: One patient was with pneumonia, 13 with COPD, 5 with bronchiectasis, 2 with kyphoscoliosis, and 2 with congestive heart failure. The median value of duration of IMV was 126 days. The weaning trial was performed on 15 of 21 patients. Six patients were not found to be appropriate for weaning. 12 of 15 patients were decannulated with $80 \%$ weaning success. Four patients were discharged with long term oxygen therapy (LTOT), nocturnal non-IMV, 7 with LTOT, and 1 without device. The patients with weaning failure had higher anxiety depression scores, systolic pulmonary arterial pressures, lower maximum inspiratory, expiratory pressures, and shorter duration of IMV.

Conclusion: This study showed that chronic respiratory failure inpatients services consisting of multidisciplinary team and integrating PR into patients' managements could serve as weaning centers in case of absence of specialized centers in prolonged MV.
\end{abstract}

Keywords: care management, chronic disease, health service staff, pulmonary rehabilitation

öz

Amaç: Akut / kronik solunum yetmezliği olan hastaları yöneten kronik solunum yetmezliği servisimiz, multidispliner ekibi ile yapılandırılmış entegre pulmoner rehabilitasyon (PR), evde bakım birimi olan hastane ünitesidir. Bu çalışmanın amacı, yatarak tedavi gören uzamış mekanik ventilasyonu (MV) olan hastalarda weaning deneyimlerimizi ve multidispliner yapılandırılmış yatan hasta kliniği modelinin weaning için alternatif bir yöntem olup olmadığını sunmaktı.

Yöntem: Multidisipliner yatarak PR programı ve weaning için evde invaziv mekanik ventilasyonu (IMV) olan 23 hasta incelendi. Dispne skorları, vücut kompozisyonları, solunum kas kuvvetleri, psikolojik durumları, PR öncesi ve weaning işleminden ekokardiyografik ölçümleri, IMV süresi (trakeostominin açılmasından bu yana), weaning öncesi ve 24 saat sonra AKG düzeyleri kaydedildi.

Bulgular: Bir hastada pnömoni, 13'ünde KOAH, 5'inde bronşektazi, 2'sinde kifoskolyoz, 2'sinde konjestif kalp yetmezliği tanısı mevcuttu. IMV süresinin ortanca değeri 126 gündü. Weaning, 21 hastanın 15'inde denenedi. 6 hasta weaning için uygun bulunmadı. 15 hastanın 12'si, \%80 weaning başarısı ile dekanüle edildi. Dört hasta uzun süreli oksijen tedavisi (USOT), nokturnal non-IMV, 7'si USOT, 1 cihazı olmadan taburcu edildi. Weaning başarısızIığı olan hastalarda daha yüksek aksiyet depresyon skorları, sistolik pulmoner arter basıncı değerleri, daha düşük maksimum inspiratuar, ekspiratuar basınçlar, daha kısa IMV süreleri mevcuttu.

Sonuç: Bu çalışma, uzun süreli MV'de uzmanlaşmış merkezlerin bulunmaması durumunda multidispliner ekibinden oluşan ve PR'nin hasta yönetimine entegre edilmesinde kronik solunum yetmezliği yatan hasta kliniklerinin weaning merkezleri olarak hizmet edebileceğini göstermiştir.

Anahtar kelimeler: bakım yönetimi, kronik hastalık, sağlık hizmetleri personeli, pulmoner rehabilitasyon
Alındığı tarih: 03 Temmuz 2020

Kabul tarihi: 22 Eylül 2020

Yayınlandığı tarih: 5 Ekim 2020

Yazışma Adresi:

I. Candemir

ORCID: 0000-0002-9877-3516

Atatürk Göğüs Hastalıkları ve Göğüs

Cerrahisi Eğitim ve Araştırma Hastanesi

Ankara - Türkiye

ipekcayli@yahoo.com

D. Kaymaz

ORCID: 0000-0001-7951-2065

F. Aktas

ORCID: 0000-0003-1256-9731

P. Ergun

ORCID: 0000-0001-7259-1223

Atatürk Göğüs Hastalıkları ve Göğüs Cerrahisi Eğitim ve Araştırma Hastanesi Ankara - Türkiye

(C) Telif hakkı SBÜ Dr. Suat Seren Göğüs Hastalıkları ve Cerrahisi Eğitim ve Araștırma Hastanesi'ne aittir. Logos Tıp Yayınclık tarafindan yayınlanmaktadır. Bu dergide yayınlanan bütün makaleler Creative Commons 4.0 Uluslararası Lisansı ile lisanslanmıştır.

(c) Copyright Journal of Izmir Chest Diseases Hospital. This journal published by Logos Medical Publishing.

Licenced by Creative Commons Attribution 4.0 International (CC) 


\section{INTRODUCTION}

Acute and acute on chronic respiratory failure are serious clinical conditions that may require hospitalization in the intensive care unit (ICU) with mechanical ventilation (MV) support and close monitoring. Since ICUs are high-cost units, expenditure of health care is increasing exponentially in the indication for prolonged IMV. For this reason, various units and centers have been designed. These units are; intermediate intensive care units, specialized regional weaning centers and long-term acute care hospitals ${ }^{(1-3)}$. These units are likely to work together with multidisciplinary pulmonary rehabilitation (PR) units, and they are also known to work in coordination with home care units. These units have been shown to reduce the number of referral to ICU and requirements of IMV ${ }^{(1,2)}$. Specialized regional weaning centers are usually located in rehabilitation centers and multidisciplinary team structure is being used to treat difficult to wean patients. Various mortality and weaning rates have been reported in these centers ${ }^{(4-9)}$. One of the other centers is the center where patients requiring more hospitalization are followed up over 25 days, defined as long-term acute care hospitals ${ }^{(10)}$. Although these hospitals are considered to be cost effective due to reducing the duration of ICU, but the survival rates and functional independency of these patients were found to be low in the first year after discharge ${ }^{(11)}$.

There are limited number of or lack of specialized weaninig center and long term acute care hospital, which are structured multidisciplinary team and collaborate with PR and home care health service units/ centers both in Turkey and some countries. Our aim was to present our chronic respiratory failure clinic where the patients with acute or acute on chronic respiratory failure were managed with multidisciplinary team structure consisted of PR center and home care unit as an alternative model in weaning period of prolonged IMV and to investigate our successfulin patients with prolonged IMV.

\section{MATERIAL and METHODS}

\section{Patient population}

The data of twenty-three patients with IMV due to weaning failure which were referred from ICU or admitted individually for the purpose of weaning between november 2010 and april 2017 were investigated retrospectively. The exclusion criterias were presence of low hemoglobin levels, kidney failure requiring hemodialysis, metabolic and hemodynamic unstability, sepsis, uncontrolled diabetes mellitus, norologic disorders ${ }^{(12)}$. The initial reasons for admission to ICU were due to respiratory failure without any surgical conditions. The approvals of patient and hospital were obtained (Atatürk Chest Disease and Chest Surgery Education and Research Hospital Review Board, decision number:571, date:31.10.2017).

\section{Multidisciplinary Team}

The clinic team was composed of 6 chest diseases specialists, 3 physiotherapists, 1 dietitian, 1 psychologist, 10 nurses, 1 elderly care technician and 1 chauffeur.

\section{Weaning Technic}

After admission to our clinic, medical treatment was reevaluated. The management of accompanying medical problems was re-assessed, and metabolic abnormalities were corrected. The respiratory medical treatment was optimized with bronchodilators and corticosteroids as indicated. The oral nutritional supplementary treatment were used according to nutritional status of patients.

Weaning trials were performed after completed antibiotic treatment and stabilized vital and infection parameters. For the purpose of both checking upper respiratory tract and communication, a cuff was deflated and the tracheostomy tube was capped off and the patients were motivated to speak $^{(13,14)}$.

IMV mode was adjusted as pressure support 
ventilation (PSV) with positive end-expiratory pressure and volume compansation with checking of arterial blood gas (ABG) levels intermittently. The unsupported spontaneous breathing (USB) trials which were during brief episodes and progressively lengthened according to individual patient progress, were included in ventilatory weaning periods. During this period, the patients were observed closely with transcutaneous monitoring providing $\mathrm{PO}_{2}$ and $\mathrm{pCO}_{2}$ levels and follow-up ABG levels whether respiratory distress occurred.

Providing that the patients were not able to increase the duration of USB because of respiratory distress or hypercapnia under optimized other medical conditions, noninvasive mechanical ventilation (NIMV) was applied through nasal or full face mask. In this practice, the tracheostomy tube was capped off and its cuff was deflated. During NIMV period, transcutaneous monitor and ABG levels were followed up. For COPD patients, inspiratory pressure was titrated to a maximum of $36 \mathrm{~cm} \mathrm{H}_{2} \mathrm{O}$ and expiratory pressure up to $6 \mathrm{~cm}$ $\mathrm{H}_{2} \mathrm{O}$. After successful USB trials in daytime, ventilatory weaning was performed at night on the same day. Oxygen therapy was given if daytime $\mathrm{pO}_{2}$ was $55 \mathrm{mmHg}$ or $60 \mathrm{mmHg}$ with cor pulmonale or polycythemia according the guidelines ${ }^{(15)}$. If hypercapnia developed while the patients were receiving oxygen therapy alone, nocturnal NIMV was added.

The patients who had successful USB or NIMV period two-three days duration were decanulated. The tracheostomy stoma was left to secondary healing.

The successfulfor prolonged IMV was defined as "complete liberation from mechanical ventilation (or a requirement for ony nocturnal NIMV) for seven consecutive days' which was recommended in 2005 report of the National Association for Medical Direction of Respiratory Care (NAMDRC) consensus conference ${ }^{(16)}$.

\section{Pulmonary Rehabilitation}

A comprehensive multidisciplinary inpatient PR program was structured. PR program consisted of exercise training, determination of body composition and support; psychological evaluation and support; and education of the patient and care givers'.

The exercise training consisted of lower and upper-extremity neuromuscular electrical stimulation (NMES) (Uniphy; Myaction Med, Bilzen, Belgium) with biphasic symmetric constant current impulses with a pulse width $300 \mathrm{~ms}$, a frequency of $50 \mathrm{~Hz}$ and a duty cycle of $10 \mathrm{~s}$ on and $20 \mathrm{~s}$ off for $20 \mathrm{~min} /$ day and also passive/ active range of motion, passive/active upper/low extremity cycling in bed/ chair, active strengthening, bronchial hygiene techniques, methods of coping with shortness of breath, and respiratory exercises. The program was structured individually. Inspiratory muscle training (IMT) consisted of an inspiratory load of 30-50 \% maximum inspiratory pressure for 5-10 minutes, twice a day and was started from begining of SBT period. The load was increased progressively according to patients' tolerance. The inpatients supervised PR program was performed consecutively five days a week for minimum 20 sessions ${ }^{(17)}$.

\section{The Measurements}

The measurements of patients were investigated retrospectively and recorded. Dyspnea scores, body composition, respiratory muscle strength, physicological status, echocardiagraphic measurements before PR and weaning process, duration of IMV (since the opening of the tracheostomy), ABG levels before and 24 hours after weaning were recorded.

Dyspnea was assessed using with Medical Research Council (MRC) scale, psychologic status with the Hospital Anxiety and Depression (HAD) (18), systolic pulmonary pressure (sPAP) and ejection fraction (EF) with echocardiography. For body composition, bio- electrical impedance was used (BIA model TBF-300; Tanita Corporation, Tokyo, Japan). Body mass index (BMI) was calculated by formula that the weight (body mass for BMI) in kilograms divided by the square of the height in meters.

Respiratory muscle strength was evaluated by 
measuring the maximal inspiratory, expiratory pressure (MIP, MEP) using an anerod maonometer (Record, Saulo Paulo, Brazil). MIP and MEP were measured with the subject in a sitting position. The patient was disconnected from the ventilator for a minimum of 20 seconds, after endotracheal aspiration and the cuff was hyperinflated. The one way valve was attached to the patients' tracheostomy tube allowing exhalation with blocking inspiration and connecting to a manometer. Tests were repeated a minimum three times, and the best value was recorded by encouraging the patients to inhale and exhale with maximum effort ${ }^{(19)}$. The predicted values of MIP and MEP were calculated according to a reference including healthy subjects ${ }^{(20)}$.

\section{Statistical Analysis}

SPSS version 18.0 (SPSS, Inc.,Chicago, USA) for Microsoft Windows (Microsoft Corporation, Redmond, Washington) was used for analysis. The variables were analysed with Shapiro-Wilks test for normal distribution. Results for descriptive statistics were expressed as mean standard deviation or median (minimummaximum). Categorical variables were expressed as numbers and percentages (\%). To assess relationships between categorical variables, the Chi-square test was used. Mann Whitney-U test was used to compare groups. The Wilcoxon signed-rank test was used for ABG levels in weaning success. Statistical significance was determined as probability value of $<0.05$.

\section{RESULTS}

Thirteen patients were with COPD, five with bronchectasis, two with kyphoscoliosis, two with congestive heart failure, one with pneumonia. Two patients died because of myocardial infarction two days after ICU (figure1). Six patients were not appropriate for weaning. Among these patients, two of them had diffuse cystic bronchiectasis, one was diagnosed as end stage fibrotic interstisial lung disease, three of them were COPD which one had epileptical seizure, two had diffuse bullous emphysema. Due to their diagnosis and medical conditions, they were not attempted to be weaned.
Flow Diagram

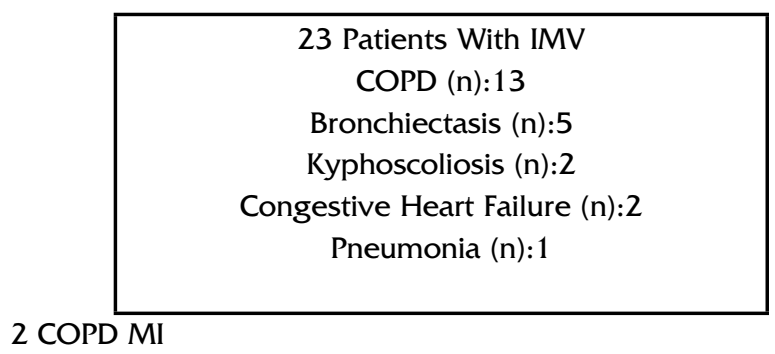

Six patients: not appropriate for weaningg diffuse cystic bronchiectasis (n):2 end stage fibrotic interstisial lungdisease (n): 1 $\operatorname{COPD}(n): 3$ one had epileptical seizure, two were with diffuse bullous emphysema

15 patients: weaningtrial COPD $(n): 8$

Bronchiectasis (n):2

Kyphoscoliosis (n):2

Congestive Heart Failure (n):2

Pneumonia (n): 1

\begin{tabular}{|c|}
\hline 12 patients: decanulated \\
COPD $(\mathrm{n}): 7$ LTOT+NIMV (n):3 \\
Bronchiectasis (n):1 LTOT \\
Kyphoscoliosis (n): 1 LTOT+NIMV \\
CHF (n):2 without device (n):1 LTOT(n): 1 \\
Pneumonia (n): 1 LTOT
\end{tabular}

Figure 1.

Fifteen patients underwent weaning trial and were enrolled into the retrospective study. Eight patients were with COPD, two were bronchiectasis, two were kyphoscoliosis, two were congestive heart failure, one was pneumonia. Twelve patients were able to wean and decanulated with $80 \%$ success. In the successful weaning group, the mean value of age was $64 \pm 10$ years. The ABG levels before and 24 hours after weaning were given in table 1. There was no statistically significant difference in $A B G$ levels before and after weaning, the median value of IMV duration was 126 days (min:30; max:600) and the median value of MIP was 43 cm $\mathrm{H}_{2} \mathrm{O}$ (min:22, max:78), MEP was $68 \mathrm{~cm} \mathrm{H}_{2} \mathrm{O}$ (min:26, max:109). They were under reference values. [According to a reference including healthy subjects, MEP values should be 135- $201 \mathrm{~cm} \mathrm{H}_{2} \mathrm{O}$ 
and MIP values should be $71-107 \mathrm{~cm} \mathrm{H}_{2} \mathrm{O}$ in successful group (in females and males respectively)]. The mean anxiety scores was $11 \pm 1.3$, depression score was $11 \pm 1.8$, the median value of $s$ PAP was $33 \mathrm{~mm} \mathrm{Hg}$ (min:22, max:55). The mean value of BMI was $25 \pm 9 \mathrm{~kg} / \mathrm{m}^{2}$. After structured follow up program, four patients were discharged with LTOT and nocturnal NIMV, seven with only LTOT, one with one device. In successful group, one patient died six month after weaning, two patients died one year after, none of the patients were recanulated or required extra device in follow-ups. Four patients were followed up for six months, five were one and over one year.

Table 1. Arterial blood gas analyses before and after weaning in successful group.

\begin{tabular}{|c|c|c|c|}
\hline & \multicolumn{2}{|c|}{ Mean \pm SD } \\
& \multicolumn{2}{|c|}{ Median (Min:maks) } & $P$ \\
\hline & Before Weaning & After Weaning & \\
\hline $\mathrm{pH}$ & $\begin{array}{c}7.40 \pm 0.03 \\
7.407 .36: 7.48)\end{array}$ & $\begin{array}{c}7.40 \pm 0.02 \\
7.40(7.36: 7.45)\end{array}$ & 0.765 \\
\hline $\begin{array}{c}\mathrm{pO}_{2} \\
(\mathrm{mmHg})\end{array}$ & $\begin{array}{c}87 \pm 27 \\
86(50: 120)\end{array}$ & $7.40 \pm 0.02$ & 0.367 \\
\hline $\begin{array}{c}\mathrm{pCO}_{2} \\
(\mathrm{mmHg})\end{array}$ & $\begin{array}{c}40 \pm 9 \\
40(25: 55)\end{array}$ & $\begin{array}{c}42 \pm 8 \\
42(31: 62)\end{array}$ & 0.271 \\
\hline
\end{tabular}

$\mathrm{pO}_{2}$ : partial oxygen pressure, $\mathrm{pCO}_{2}$ : partial carbondioxide pressure

In the three patients who failed to be weaned, 2 of them were male with ages of 45 (40:71) years. and the median value of MIP was $20 \mathrm{~cm} \mathrm{H}_{2} \mathrm{O}$


max:57). They were under reference values. According to a reference including healthy subjects, MEP values should be 146- $222 \mathrm{~cm} \mathrm{H}_{2} \mathrm{O}$ and MIP values should be $81-118 \mathrm{~cm} \mathrm{H}_{2} \mathrm{O}$ in failure group (in females and males respectively).

When two group were compared; MIP and MEP values were lower, HAD scores, s PAP evaluated by echocardiography were found to be higher and contrary to expectation, the duration of IMV was shorter than successful group. According to statistical analysis, only MIP values were statistically different $(p=0.031)$. The groups were statistically similar in terms of age $(p=0.308)$, sex $(p=0.790)$, IMV duration (0.066), MEP $(p=0.201)$, BMI $(p=0.304)$, $s$ PAP $(p=0.127)$, EF values $(p=0.218)$ and MRC $(p=0.922)$, anxiety $(p=0.163)$, depression scores $(p=0.113)$ (table 2.). The parameters were given in table 2 .

\section{DISCUSSION}

In this retrospective observational study which presented our clinical experience, it was shown that although there was no clear clinically important parameter for successful in prolonged $M V$, respiratory muscle strength, psychological status, pulmonary hypertension could be important but most important considerable factor was seem to be comprehensive multidisciplinary approach which consisted of pulmonary rehabilitation and home care.

The number of cases requiring MV is increasing due to reasons such as the development of chronic care strategies and the increase of the elderly population. Thus, there is an increase in the proportion of cases requiring prolonged MV. Prolonged MV is defined as requiring MV more than 21 consecutive days and more than 6 hours (16). Prolonged MV has been shown as an important prognostic indicator of successful ${ }^{(21,22)}$, and success of weaning has been found to be various as $38-78 \%$ of cases in this group compared to other weaning failure reasons. The reasons of weaning failure in prolonged $\mathrm{MV}$ has been shown as COPD, neuromuscular disease, high body mass index (BMI), pneumonia, high positive expiratory pressure in various studies ${ }^{(23,24)}$. However, the accurate clinical factors affecting the success or failure of weaning have not been revealed in these patients due to several definitions of pronlonged MV (25).

In a recent study, the duration of $M V$ was found to be $\mathbf{4 2}$ days in the successful group and 31 days in the failure group, and the difference was statistically significant. In addition, in successful group the number of patients with cardiovascular disease was significantly more than patients with respiratory disease ${ }^{(25)}$. In our study, in the patients of successful group, duration of IMV were longer than other group. The duration of IMV was not 
Table 2. Parameters of successfuland failure group

\begin{tabular}{|c|c|c|c|}
\hline & Successful group $(n=12)$ & weaning failure group $(n=3)$ & $\mathbf{p}$ \\
\hline Sex (male/female) & $7(58 \%) / 5(42 \%)$ & $2(67 \%) / 1(33 \%)$ & 0.790 \\
\hline Age (year) & $\begin{array}{c}65 \pm 10 \\
65(36: 78)\end{array}$ & $\begin{array}{c}52 \pm 16 \\
45(40: 71)\end{array}$ & 0.308 \\
\hline $\begin{array}{c}\text { IMV } \\
\text { duration (days) }\end{array}$ & $\begin{array}{c}228 \pm 201 \\
126(30: 600)\end{array}$ & $\begin{array}{c}45 \pm 21 \\
45(30: 60)\end{array}$ & 0.066 \\
\hline $\mathbf{p H}$ & $\begin{array}{c}7.40 \pm 0.03 \\
7.40(7.36: 7.48)\end{array}$ & $\begin{array}{c}7.45 \pm 0.06 \\
7.48(7.38: 7.49)\end{array}$ & 0.246 \\
\hline $\mathrm{pO}_{2}(\mathrm{mmHg})$ & $\begin{array}{c}87 \pm 27 \\
86(50: 120)\end{array}$ & $\begin{array}{c}89 \pm 17 \\
82(77: 109)\end{array}$ & 0.828 \\
\hline $\mathrm{PCO}_{2}(\mathrm{mmHg})$ & $\begin{array}{c}40 \pm 9 \\
40(25: 55)\end{array}$ & $\begin{array}{c}44 \pm 15 \\
43(30: 60)\end{array}$ & 0.718 \\
\hline MIP $\left(\mathrm{cmH}_{2} \mathrm{O}\right)$ & $\begin{array}{c}45 \pm 19 \\
43(22: 78)\end{array}$ & $\begin{array}{c}22 \pm 4 \\
20(20: 27)\end{array}$ & 0.030 \\
\hline $\operatorname{MEP}\left(\mathrm{cmH}_{2} \mathbf{O}\right)$ & $\begin{array}{c}66 \pm 26 \\
68(26: 109)\end{array}$ & $\begin{array}{c}39 \pm 25 \\
39(21: 57)\end{array}$ & 0.201 \\
\hline MRC & $\begin{array}{c}4.6 \pm 0.6 \\
4(3: 5)\end{array}$ & $\begin{array}{c}4.6 \pm 0.5 \\
5(4: 5)\end{array}$ & 0.922 \\
\hline BMI $\left(\mathbf{k g} / \mathbf{m}^{2}\right)$ & $\begin{array}{c}25 \pm 9 \\
21(17: 46)\end{array}$ & $\begin{array}{c}19 \pm 3.4 \\
21(15: 21)\end{array}$ & 0.304 \\
\hline Anxiety score & $\begin{array}{c}11 \pm 1.3 \\
11(10: 14)\end{array}$ & $\begin{array}{c}12 \pm 1 \\
12(11: 13)\end{array}$ & 0.163 \\
\hline Depression score & $\begin{array}{c}11 \pm 1.8 \\
11(8: 14)\end{array}$ & $\begin{array}{c}12.6 \pm 0.5 \\
13(12: 13)\end{array}$ & 0.113 \\
\hline sPAP (mmHg) & $\begin{array}{c}37 \pm 10 \\
33(22: 55)\end{array}$ & $\begin{array}{c}44.3 \pm 1.1 \\
45(43: 45)\end{array}$ & 0.127 \\
\hline Ef\% & $\begin{array}{c}58 \pm 6 \\
59(45: 65)\end{array}$ & $\begin{array}{c}55 \pm 5 \\
55(50: 60)\end{array}$ & 0.218 \\
\hline
\end{tabular}

IMV: invasive mechanical ventilation, $\mathrm{pO}_{2}$ : partial oxygen pressure, $\mathrm{pCO}_{2}$ : partial carbondioxide pressure, MIP: maximum inspiratory pressure, MEP: maximum ekspiratory pressure, BMI: body mass index, sPAP: sistolic pulmonary arterial pressure, ef:ejection fraction

be seemed to be factor for success of weaning, it was suggested that it could be due to the respiratory muscle training as a compenent of PR. Furthermore in our study, two patients with CHF were weaned successfully and although most of the patients had COPD, the rate of success was high which suggested as COPD being not likely be a risk factor for weaning. The weaning failure group of pateints had higher SPAP, whether the presence of possible pulmonary hypertension was thought to be indicative of the severity of the disease, advanced disease might be determinant instead of diagnosis of disease in weaning failure.

Other important consequences of prolonged MV are psychological disorders. In a study of 478 patients followed up for weaning in a longterm acute care hospital, it was found that $42 \%$ of patients weaned after prolonged MV were diagnosed with depressive disorder and weaning failure and mortality were found to be higher in depressive patients ${ }^{(26)}$. Similarly, our study showed that psychological status assessed by using HAD score was be higher in weaning failure group. Another risk factor that has been already shown is respiratory muscle strength. A reduction of $25 \%$ in diaphragmatic muscle cross-section has been shown even for an average of 7 IMV days ${ }^{(27)}$. The MIP value below $20 \mathrm{~cm} \mathrm{H}_{2} \mathrm{O}$ has been found to be associated with weaning failure. In 2016 in a study with 6583 patients, it was shown that a significant relationship between age, sex, disease severity, MIP, MEP values and successfuland MEP values were found to be an independent predictor of weaning success. Additionally, it was emphasized that MIP and MEP 
cut off values should be above $55 \mathrm{~cm} \mathrm{H}_{2} \mathrm{O}^{(28)}$. In our study, in successful group although the value of MIP was found under $55 \mathrm{~cm} \mathrm{H}_{2} \mathrm{O}$, MEP was above 55 and both of MIP and MEP values were shown to be higher than weaning failure group. Although MIP and MEP were higher in successful group than weaning failure group, only MIP values were statistically different. We suggested that it could be due to low normal of patients and the importance of MIP values in weaning process. Furthermore, the contribution of IMT was suggested in the patients with decreased values in successful group. In recent study, individualized and supervised PR programs consisting of IMT were recommended in ICU ${ }^{(29)}$.

Different percentages of successful weaning have been reported in various studies. In a recent study in 2017, success was 32.3\% in 127 patients who were followed up for prolonged MV in ICU and it was suggested that the low success rate could be linked to the fact that the center was not the spesific weaning center ${ }^{(25)}$. In another study in 2010, successful was reported as 53\% after prolonged MV in 144 patients in the weaning center where pulmonary rehabilitation was also performed ${ }^{(30)}$. In a multi-center study, in 1.419 patients who were difficult to wean, the success was found to be $54 \%$ in long-term acute care hospitals, whereas weaning centers were shown to have a $34-60 \%$ success rate in observational studies ${ }^{(31,32)}$. Although it was not convenient to compare different centers and periods, successful weaning has been shown to be linked to the anatomy, complexity, comorbidities of patients, hospital organization, staff experience, early onset PR, weaning protocols, preparation and education of family and caregivers ${ }^{(33-35)}$. In particular, the importance of PR, which was initiated in the ICU period, has been emphasized ${ }^{(36-38)}$. In our study, success was higher which suggested that higher rate was due to comprehensive PR program immediately before weaning.

Limitations of our study can be listed as limited number of patients and single-center design.

\section{CONCLUSION}

This study showed that chronic respiratory failure inpatients services consisting of multidisciplinary team and integrating PR into patients' managements could serve as weaning centers in case of absence of specialized centers in prolonged MV. Although possible clinical factors of successful were not revealed, in this model, the weaning success was found to be similar to the experienced weaning centers in other countries. Furthermore, this service delivery model might increase the success of weaning in the prolonged mechanical ventilation and improve the success rate in our country.

Ethics Committee Approval: T.C. Ankara Governorship Health Sciences University Ankara Atatürk Chest Diseases and Thoracic Surgery Training and Research Hospital Ethics Committee approval was obtained (31.10.2017/571).

Conflict of Interest: There is no conflict of interest between the authors.

Funding: No financial support was received for the study.

\section{REFERENCES}

1. Ambrosino, N. and Vagheggini, G. Noninvasive positive pressure ventilation in the acute care setting: where are we?. Eur Respir J. 2008;31:874-86 https://doi.org/10.1183/09031936.00143507

2. Nava, S. and Hill, N. Non-invasive ventilation in acute respiratory failure. Lancet. 2009;374:250-9. https://doi.org/10.1016/S0140-6736(09)60496-7

3. Béduneau, G., Pham, T., Schortgen, F., Piquilloud, L., Zogheib, E., Jonas, M., the REVA (Réseau Européen de Recherche en Ventilation Artificielle) Network. Epidemiology of weaning outcome according to a new definition. The WIND Study. American Journal of Respiratory and Critical Care Med. 2017;195(6):1-55. https://doi.org/10.1164/rccm.201602-03200C.

4. Thomsen, G.E., Snow, G.L., Rodriguez, L.A.S., and Hopkins, R.O. Patients with respiratory failure increase ambulation after transfer to an intensive care unit where early activity is a priority. Crit Care Med. 2008;36:1119-24 https://doi.org/10.1097/CCM.0b013e318168f986

5. Corrado, A., Roussos, C., Ambrosino, N., Confalonieri, M., 
Cuvelier, A., Elliott, $M$. et al. Respiratory intermediate care units: a European survey. Eur Respir J. 2002;20: 1343-50 https://doi.org/10.1183/09031936.02.00058202

6. Confalonieri, M., Gorini, M., Ambrosino, N., Mollica, C., and Corrado, A. Scientific group on Respiratory Intensive Care of the Italian Association of Hospital Pneumonologists. Respiratory intensive care units in Italy: a national census and prospective cohort study. Thorax. 2001;56:373-8 https://doi.org/10.1136/thorax.56.5.373

7. Polverino, E., Nava, S., Ferrer, M., Ceriana, P., Clini, E., Spada, E. et al. Patients' characterization, hospital course and clinical outcomes in five Italian respiratory intensive care units. Intensive Care Med. 2010; 36: 137-42 https://doi.org/10.1007/s00134-009-1658-2

8. Vitacca, M., Vianello, A., Colombo, D., Clini, E., Porta, R., Bianchi, L. et al. Comparison of two methods for weaning patients with chronic obstructive pulmonary disease requiring mechanical ventilation for more than 15 days. Am J Respir Crit Care Med. 2001; 164: 225-30 https://doi.org/10.1164/ajrccm.164.2.2008160

9. Scheinhorn, D.J., Chao, D.C., Stearn-Hassenpflug, M., LaBree, L.D., and Heltsley, D.J. Post-ICU mechanical ventilation: treatment of 1,123 patients at a regional weaning center. Chest. 1997; 111: 1654-9 https://doi.org/10.1378/chest.111.6.1654

10. Burtin, C., Clerckx, B., Robbeets, C., Ferdinande, P., Langer, D., Troosters, T. et al. Early exercise in critically ill patients enhances short-term functional recovery. Crit Care Med. 2009; 37: 2499-505 https://doi.org/10.1097/CCM.0b013e3181a38937

11. Bagley, P.H. and Cooney, E. A community-based regional ventilator weaning unit: development and outcomes. Chest. 1997; 111: 1024-9. https://doi.org/10.1378/chest.111.4.1024

12. Maclntyre NR, Cook SJ, Ely EW, Epstein SK, Fink JB, Heffner JE, Hess D, Hubmayer RD, Scheinhorn DJ. Evidence-based Guidelines for Weaning and Discontinuing Ventilatory Support: A Collective Task Force Facilitated by the American College of Chest Physicians; The American Association for Respiratory Care; And the American College of Critical Care Medicine. Chest. 2001;120 (6):375S-95S.

https://doi.org/10.1378/chest.120.6_suppl.375S

13. Hess DR. Facilitating speech in the patient with a tracheostomy. Respir Care 2005;50(4):519-25.

14. Johnson DC, Campbell SL, Rabkin JD. Tracheostomy tube manometry: evaluation of speaking valves, capping and need for downsizing.Clin Respir J 2008;3(1):8-14. https://doi.org/10.1111/j.1752-699X.2008.00100.x

15. Hardinge M, Annandale J, Bourne S, Cooper B, Evans A, Freeman D, et al. British Thoracic Society Home Oxygen Guideline Development Group; British Thoracic Society
Standards of Care Committee. British Thoracic Society guidelines for home oxygen use in adults. Thorax.2015;70(1),1-43.

https://doi.org/10.1136/thoraxjnl-2015-206865.

16. MacIntyre NR, Epstein SK, Carson S, et al. Management of patients requiring prolonged mechanical ventilation: report of a NAMDRC consensus conference. Chest 2005; 128:3937-54.

https://doi.org/10.1378/chest.128.6.3937

17. Spruit MA, et al. ATS/ERS Task Force on Pulmonary Rehabilitation, An official American Thoracic Society/ European Respiratory Society statement: key concepts and advances in pulmonary rehabilitation. Am J Respir Crit Care Med. 2013;188:e13-64.

18. Aydemir O, Güvenir T, Küey L, Kültür S. Reliability and Validity of the Turkish version of Hospital Anxiety and Depression Scale. Turk J Psychiatry 1997; 8:280-7.

19. Caruso P, Friedrich C, Denari SD, Ruiz SA, Deheinzelin D. The unidirectional valve is the best method to determine mip during weaning. Chest 1999; 115: 1096-101. https://doi.org/10.1378/chest.115.4.1096

20. Black LF, Hyatt RE. Maximal respiratory pressures: normal values and relationship to age and sex. Am Rev Respir Dis 1969; 99: 696-702.

21. Engoren $M$, Arslanian-Engoren C, Fenn-Buderer $N$. Hospital and long-term outcome after tracheostomy for respiratory failure. Chest 2004;125:220-7. https://doi.org/10.1378/chest.125.1.220

22. Bigatello LM, Stelfox HT, Berra L, et al. Outcome of patients undergoing prolonged mechanical ventilation after critical illness. Crit Care Med 2007;35:2491-7. https://doi.org/10.1097/01.CCM.0000287589.16724.B2

23. Mamary AJ, Kondapaneni S, Vance GB, et al. Survival in Patients Receiving Prolonged Ventilation: Factors that Influence Outcome. Clin Med Insights Circ Respir Pulm Med 2011;5:17-26.

https://doi.org/10.4137/CCRPM.S6649

24. Pan C, Qiu H. Improve survival from prolonged mechanical ventilation: beginning with first step. J Thorac Dis 2015; 7:1076-9.

25. Shin H, Chang J, Ahn S, Kim T, Park C, Lim J, Oh I, Lim $S$, Kwon Y. Clinical factors associated with weaning failure in patients requiring prolonged mechanical ventilation. J Thorac Dis 2017;9(1):143-50 https://doi.org/10.21037/jtd.2017.01.14

26. Jubran A, Lawm G, Kelly J, Duffner LA, Gungor G, Collins EG, Lanuza DM. Depressive Disorders during Weaning from Prolonged Mechanical Ventilation. Inten Care Med. 2010; 36(5): 828-35. https://doi.org/10.1007/s00134-010-1842-4

27. Hooijman PE, Beishuizen A, Witt CC, de Waard MC, Girbes AR, Spoelstra-de Man AM, et al. Diaphragm muscle fiber weakness and ubiquitin-proteasome activa- 
tion in critically ill patients. Am J Respir Crit Care Med. 2015; 191:1126-38. https://doi.org/10.1164/rccm.201412-2214OC

28. Lai C, Chen C, Chiang SR, Liu WL, Weng SF, Sung MI, Hsing SC, Cheng KC. Establishing predictors for successfully planned endotracheal extubation. Med Balti 2016; 95(41):48-52. https://doi.org/10.1097/MD.0000000000004852

29. Magalhães P, Camillo CA, Langer D, Andrade LB, Duart MC.MB, Gosselink R. Weaning failure and respiratory muscle function: What has been done and what can be improved? Respiratory Med 2018; 134: 54-61. https://doi.org/10.1016/j.rmed.2017.11.023

30. Carpenè N, Vagheggini G, Panait E, Gabbrielli L, Ambrosino N. A proposal of a new model for long-term weaning: respiratory intensive care unit and weaning center. Respir Med 2010; 104: 1505-11 https://doi.org/10.1016/j.rmed.2010.05.012

31. Rudy, E.B., Daly, B.J., Douglas, S., Montenegro, H.D., Song, R., and Dyer, M.A. Patient outcome for the chronically critically ill: special care unit versus intensive care unit. Nurs Res. 1995; 44: 324-31 https://doi.org/10.1097/00006199-199511000-00002

32. Seneff, M.G., Wagner, D., Thompson, D., Honeycutt, C., and Silver, M.R. The impact of long-term acute-care facilities on the outcome and cost of care for patients undergoing prolonged mechanical ventilation. Crit Care Med. 2000; 28: 342-50 https://doi.org/10.1097/00003246-200002000-00009

33. Hodgin, K.E., Nordon-Craft, A., McFann, K.K., Mealer,
M.L., and Moss, M. Physical therapy utilization in intensive care units: results from a national survey. Crit Care Med. 2009; 37: 561-8 https://doi.org/10.1097/CCM.0b013e3181957449

34. Burtin, C., Clerckx, B., Robbeets, C., Ferdinande, P., Langer, D., Troosters, T. et al. Early exercise in critically ill patients enhances short-term functional recovery. Crit Care Med. 2009; 37: 2499-505 https://doi.org/10.1097/CCM.0b013e3181a38937

35. Bagley, P.H. and Cooney, E. A community-based regional ventilator weaning unit: development and outcomes. Chest. 1997; 111: 1024-29 https://doi.org/10.1378/chest.111.4.1024

36. Schweickert, W.D., Pohlman, M.C., Pohlman, A.S., Nigos, C., Pawlik, A.J., Esbrook, C.L. et al. Early physical and occupational therapy in mechanically ventilated, critically ill patients: a randomised controlled trial. Lancet. 2009; 373: 1874-82 https://doi.org/10.1016/S0140-6736(09)60658-9

37. Porta, R., Vitacca, M., Gilè, L.S., Clini, E., Bianchi, L., Zanotti, E., and Ambrosino, N. Supported arm training in patients recently weaned from mechanical ventilation. Chest. 2005; 128: 2511-20 https://doi.org/10.1378/chest.128.4.2511

38. Verceles AC, Wells ML, Sorkin AD, Terrin ML, Beans J, Jenkins T, Goldberg AP. A multimodal rehabilitation program for patients with ICU acquired weakness improves ventilator weaning and discharge home. J Critic Care. 2018; 47:204-10. https://doi.org/10.1016/j.jcrc.2018.07.006 